ISSN: $2338-4794$

Vol.6. No. 3 Sept.- Des. 2018

\title{
PENGARUH PERIKLANAN DAN CITRA MEREK TERHADAP KEPUTUSAN PEMBELIAN HANDPHONE MEREK SAMSUNG
}

\author{
Winda Pramita ${ }^{1)}$ \\ 1) Mahasiswa Program Studi Manajemen FE Unkris \\ Iwan Kurniawan Subagja ${ }^{2)}$ \\ 2) Dosen Program Studi Manajemen FE Unkris \\ Kampus Unkris Jatiwaringin PO BOX 7774/Jat CM Jakarta 13077 \\ Email: iwankurniawan@unkris.ac.id
}

\begin{abstract}
This study aims to analyze the influence of advertising and brand image on Samsung brand purchasing decisions. The population in this study were 137 students of the Faculty of Economics, University of Krisnadwipayana who used Samsung smartphones consisting of 84 students majoring in management and 53 students majoring in accounting. The sampling technique in this study used a non-probability sampling technique, which used purposive sampling technique, which was an economics faculty student who used a Samsung mobile phone and who had seen a Samsung advertisement. The results showed that there was an influence of advertising and brand image on the purchase decision of the Samsung brand at the Faculty of Economics at University of Krisnadwipayana.
\end{abstract}

Keywords: Advertising, image and purchasing decisions

\section{PENDAHULUAN}

Komunikasi merupakan prasyarat kehidupan manusia. Karena tanpa komunikasi, interaksi antar manusia tidak mungkin terjadi. Pada zaman modern seperti saat ini, suatu kebutuhan komunikasi adalah hal yang sangat penting bagi semua kalangan masyarakat. Kebutuhan komunikasi tersebut berdampak pada meningkatnya permintaan akan berbagai jenis alat komunikasi. Perkembangan teknologi berlangsung sedemikian pesatnya, banyak alat komunikasi kini telah mengalami perubahan. Perubahan yang sering terjadi terutama disebabkan oleh potensi dan kemampuan tekonologi komunikasi tersebut, yang memungkinkan manusia untuk saling berhubungan dan memenuhi kebutuhan komunikasi mereka setiap saat. Telepon genggam adalah salah satu alat komunikasi yang selalu mengalami perkembangan setiap tahunnya. Telepon genggam atau handphone, kini telah berevolusi menjadi telepon pintar yang biasa disebut dengan smartphone. Smartphone adalah telepon genggam yang memiliki keunggulan multi-tasking yang dapat memberikan kemudahan bagi para konsumen dalam melakukan kegiatan komunikasi maupun kegiatan lainnya. Saat ini banyak sekali merek smartphone yang ditawarkan di Indonesia. Salah satu perusahaan yang memproduksi smartphone berbasis Android adalah Samsung.

Samsung adalah perusahaan yang berasal dari Korea Selatan yang didirikan oleh Lee Byung Chull dan Kang Gary pada tahun 1938. Samsung (yang dalam bahasa Korea berarti tiga bintang) beroperasi di 6 (enam) bidang yaitu peralatan rumah tangga digital, telekomunikasi, media digital, LCD, semikonduktor dan Kendaraan bermotor (termasuk alat berat). Perusahaan Samsung kini beroperasi di 58 negara dan memiliki lebih dari 208.000 pekerja. Samsung menjadi salah satu produsen smartphone terbesar di dunia saat ini. Kesuksesan Samsung dimulai setelah meluncurkan 
produk smartphone dengan sistem operasi Android, bernama Samsung Galaxi S yang diluncurkan pada tahun 2010 dan tingkat penjualan handphone ini cukup tinggi.

Menurut Kotler dan Keller (2009) "Keputusan pembelian adalah proses psikologis dasar yang memainkan peranan penting dalam memahami cara konsumen benar-benar membuat keputusan pembelian". Saat ini banyak sekali muncul merek-merek smartphone baru dengan masing-masing keunggulan yang ditawarkan, Hal ini membuat konsumen memiliki banyak pilihan, yang membuat konsumen semakin selektif dalam memilih handphone yang mereka inginkan. Hal umum yang biasanya konsumen pertimbangkan sebelum membeli handphone adalah harga, fitur, daya tahan produk, garansi dan jaminan yang diberikan. Tak jarang rekomendasi dari oranglain juga menjadi salah satu faktor penentu konsumen memutuskan untuk membeli smartphone atau tidak.

Samsung menawarkan kualitas produk yang tinggi, daya tahan produk yang baik dengan fitur dan desain terbaru, selain itu Samsung juga menyediakan beberapa tingkatan harga beragam yang mampu menjangkau berbagai kalangan masyarakat, khususnya masyarakat Indonesia. Samsung juga selalu aktif memproduksi smartphone dengan fiturfitur baru di setiap tahunnya. Samsung selalu menciptakan inovasi baru yang berbeda dengan merek pesaingnya. Karena hal ini lah, kini Samsung menjadi pemimpin pasar (Leader Market) di dunia bisnis gadget. Hasil Riset IDC (International Data Coporation) mencatat selama tahun 2017 Samsung masih merajai pangsa pasar di global dan pangsa pasar di Indonesia. Pangsa pasar sebesar 23,3\% dan total pengiriman di seluruh dunia sebersar 83,3 juta unit (Sumber: www.IDC.com.)

Menurut Kotler (2009) "dalam pemasaran (marketing) ada delapan bauran komunikasi pemasaran yaitu periklanan (Advertising), Promosi Penjualan (Sales
Promotion), Pemasaran sponsorship (Event Sponsorship), Publisitas (Publicity), Penjualan Langsung (Direct Marketing), Penjualan perseorangan (Personal Selling), Penjualan Interaktif (Interactive Marketing), WOM (World of Mouth)". Menurut Kotler (2009) "Periklanan adalah semua bentuk terbayar atas persentasi non pribadi dan promosi ide, barang, atau jasa oleh suatu sponsor yang jelas."

Salah satu strategi komunikasi pemasaran yang dilakukan Samsung adalah dengan melakukan periklanan. Perusahaan Samsung sadar akan fakta bahwa perusahaan yang dapat bertahan di dunia bisnis adalah perusahaan yang selalu ada di di benak ingatan masyarakat. Oleh karena itu, Samsung selalu mengadakan kegiatan periklanan dalam rangka mempromosikan produk-produk terbarunya. Hal ini dilakukan untuk memperkenalkan produk smartphone Samsung terbaru sekaligus untuk menarik minat beli konsumen. Seperti pada Samsung Galaxy S9, perusahaan Samsung sudah gencar membuat iklan dan memperkenalkan produknya melalui media internet atau iklan di TV sebelum produk tersebut launching di pasar Indonesia. Iklan tersebut memiliki tag-line "Pre Order Now" Melalui iklan tersebut, konsumen diajak untuk memesan handphone Samsung Galaxy S9 dengan sistem pre-order. Samsung Galaxy S9 memiliki keunggulan tampilan layar edge yang lebih besar sehingga memiliki luas pandang yang lebih lebar. Melalui iklan, perusahaan Samsung berusaha untuk menyampaikan pesan mengenai produk terbarunya dan membangun citra merek perusahaan kepada masyarakat luas. Oleh karena itu periklanan merupakan faktor penting yang dapat mempengaruhi keputusan pembelian. Hal ini diperkuat dengan penelitian yang dilakukan oleh Wahyuni (2016).

Menurut Tjiptono (2005) "Citra Merek (Brand Image) adalah deskripsi dan keyakinan konsumen terhadap merek tertentu." Biasanya calon konsumen 
memilih handphone dengan merek yang sudah familiar di kalangan masyarakat. Hal tersebut bisa jadi dikarenakan produk terebut sudah lama beredar di pasaran, maka produk tersebut dianggap memiliki keunggulan yang lebih baik dibanding merek lain. Smartphone merek Samsung sudah cukup dikenal masyarakat dengan kualitas dan ketahan produk yang tinggi. Karna keunggulan produk ini lah, merek Samsung dipandang sebagai merek high class atau kelas atas. Ketika citra merek Samsung sudah baik di mata konsumen, tentu hal ini akan mempermudah perusahaan untuk meningkatkan penjualan perusahaan. Terbukti sampai saat ini Samsung selalu merajai pangsa pasar smartphone di global ataupun di Indonesia. Ini berarti bahwa citra merek yang baik dapat mempengaruhi keputusan pembelian. Hal ini sejalan dengan penelitian terdahulu yang dilakukan oleh Amilia dan Asmara tahun 2017.

Peneliti memilih Handphone Samsung karena Samsung saat ini sudah menjadi salah satu vendor smartphone yang dikenal masyarakat luas, khususnya masyarakat Indonesia. Brand image perlu dibentuk, ditingkatkan, dan dijaga di benak konsumen agar terciptanya citra merek yang positif. Citra merek yang positif nantinya akan menciptakan sebuah loyalitas konsumen terhadap merek tersebut. selain karna citra merek yang sudah baik, Samsung merupakan salah satu perusahaan smartphone yang paling gencar mengadakan promosi melalui iklan, baik iklan di media televisi ataupun internet. Tidak perduli seberapa unggul dan terkenal merek suatu perusahaan, jika tidak melakukan promosi maka merek tersebut cepat atau lambat akan terlupakan oleh masyarakat. Baik iklan maupun citra merek, kedua hal tersebut sangatlah berpengaruh terhadap keputusan pembelian konsumen. Hal ini diperkuat oleh penelitian terdahulu yang dilakukan oleh Prakoso (2015) mengatakan bahwa harga, iklan dan citra merek berpengaruh secara simultan dan signifikan terhadap keputusan pembelian smartphone Android Samsung.

\section{LANDASAN TEORI}

\section{Keputusan Pembelian}

Menurut Peter dan Olson (2013) "keputusan pembelian adalah proses integritas yang dilakukan untuk mengkombinasian pengetahuan guna mengevaluasi dua atau lebih alternatif dan memilih satu diantaranya". Menurut Setiadi (dalam Sangadji dan Sopiah, 2013) "keputusan konsumen adalah proses pengintegrasian yang mengombinasikan pengetahuan untuk mengevaluasi dua perilaku alternatif atau lebih, dan memilih salah satu diantaranya". Menurut Kotler dan Keller (2013) "keputusan pembelian adalah suatu tahap dimana konsumen telah memiliki pilihan dan siap untuk melakukan pembelian atau pertukaran antara uang dan janji untuk membayar dengan hak kepemilikan atau penggunaan suatu barang atau jasa". Menurut Alma (2013) "keputusan pembelian adalah suatu keputusan konsumen yang dipengaruhi oleh ekonomi keuangan, tekonologi, politik, budaya, produk, harga, lokasi, promosi, manusia, dan proses, sehingga membentuk suatu sikap pada konsumen untuk mengolah segala informasi dan mengambil kesimpulan berupa respons yang muncul produk apa yang akan dibeli". Definsi lain eputusan pembelian menurut Kotler dan Armstrong (2016) "keputusan pembelian merupakan bagian dari perilaku konsumen yaitu studi tentang bagaimana individu, kelompok dan organisasi memilih, membeli, menggunakan dan bagaimana barang, jasa, ide atau pengalaman untuk memuaskan kebutuhan dan keinginan mereka".

Dalam penelitian ini digunakan beberapa indikator dalam pengukuran variabel keputusan pembelian. "Menurut Kotler (2007) indikator dari keputusan pembelian antara lain: 1). Kemantapan pada sebuah produk. 2). Memberikan 
rekomendasi kepada orang lain. 3). Melakukan pembelian ulang."

\section{Periklanan}

Menurut Hasan (2014) "periklanan merupakan upaya perusahaan menyampaikan promosi non-personal untuk mempengaruhi konsumen membeli produk yang ditawarkan perusahaan". Menurut Hamdani (2014) "periklanan merupakan salah satu bentuk dari komunikasi impersonal yang digunakan oleh perusahaan untuk memberikan informasi tentang suatu produk atau jasa." Menurut Kotler \& Amstrong (2014) "Periklanan adalah pesan yang disampaikan secara masal kepada seluruh calon pembeli. Penjual dapat mengulang kembali pesan yang ingin disampaikan dengan jumlah yang diinginkan". Iklan Menurut Kotler \& Keller (2012) "iklan adalah semua bentuk terbayar dari presentasi nonpersonal dan promosi ide, barang atau jasa melalui sponsor yang jelas melalui media cetak (Koran dan majalah), media penyiaran (radio dan televisi), media jaringan (telepon, kabel, satellite, wireless), dan media elektronik (rekaman suara, rekaman video, CDROM, halaman website) dan media pameran (Billboard, papan petunjuk jalan, dan poster)." Menurut Lupiyoadi (2014) "Periklanan merupakan salah satu bentuk dari komunikasi impersonal (impersonal communication) yang digunakan oleh perusahaan dalam mengkomunikasikan produknya, baik barang maupun jasa".

Indikator periklanan menurut Kotler (2007) terdapat lima indikator periklanan, antara lain: 1). Misi (Mission) yaitu menetapkan tujuan periklanan yang membujuk pada keputusan sebelumnya mengenai pasar sasaran, penentuan pasar sasaran, penentuan posisi pasar, dan bauran promosi. 2). Pesan yang disampaikan (message) idealnya suatu pesan harus mendapat perhatian, menarik, membangkitkan keinginan, dan menghasilkan tindakan. 3). Media (Media) yang digunakan pada dasarnya pemilihan media adalah mencari cara dengan biaya yang paling efektif untuk menyampaikan sejumlah pemberitahuan iklan terhadap khalayak sasaran tergantung kepada jangkauan, frekuensi, dan dampak iklan."

\section{Citra Merek}

Menurut Keller (2013), "citra merek adalah sifat merek yang membuat suatu merek menjadi unik yang ada dalam ingatan konsumen". Menurut Hasan (2014) "citra merek merupakan serangkaian sifat berwujud dan tidak berwujud seperti ide, keyakinan, nilainilai, kepentingan dan fitur yang membuat suatu merek menjadi unik", sedangkan menurut Kotler \& Amstrong (2014) “citra merek adalah sekumpulan keyakinan terhadap merek." Pengertian lain citra merek menurut Tjiptono (2015) "citra merek merupakan pengamatan dan kepercayaan yang digenggam konsumen, seperti yang dicerminkan di dalam benak konsumen". Menurut Kotler dan Keller (2012) menyatakan bahwa "citra merek adalah cara persepsi masyarakat menganggap merek secara aktual terhadap perusahaan atau produknya."

Indikator dari "citra merek menurut Aaker dan Biel (2009) antara lain: 1). Citra pembuat (corporate image); Citra Pembuat adalah sekumpulan asosiasi yang di persepsikan konsumen terhadap kredibiltas perusahaan yang membuat suatu barang. Citra pembuat meliputi kredibilitas sebuah perusahaan yang memberikan kesan professional dan keahlian dibidang apa yang dijualnya, popularitas perusahaan di benak konsumen, dan jaringan perusahaan. 2). Citra pemakai (user image); Citra pemakai adalah persepsi yang di ciptakan konsumen tentang pengenalan produk, jenis konsumen dan status sosial yang membeli dan menggunakan produk tersebut. 3). Citra produk (product image); Citra Produk adalah sekumpulan asosiasi yang dipersepsikan konsumen terhadap barang atau jasa tertentu, hal ini meliputi kualitas dari produk barang, daya tahan, 
Harga produk, manfaat bagi konsumen, dan jaminan yang diberikan."

\section{METODE PENELITIAN}

\section{Rancangan Penelitian}

Rancangan penelitian ini adalah untuk menganalisis hubungan kausalitas anatara periklanan dan citra merek terhadap keputusan pembelian handphone Samsung. Responden dalam penelitian ini adalah mahasiswa Fakultas Ekonomi Universitas Krisnadwipayana yang menggunakan handphone merek Samsung, metode analisis yang digunakan dalam penelitian ini adalah analisis deskriptif, regresi linier sederhana dan regresi linier berganda.

\section{Jenis dan Sumber Data}

Jenis data dalam penelitian ini yaitu data subjek dan data dokumenter. Data subjek merupakan data yang diperoleh melalui jawaban responden melalui wawancara, pengisian kuesioner dan observasi. Data subjek menjelaskan tentang karaterisitik dari sekelompok orang yang dijadikan subjek penelitian (responden). Data dokumenter dalam penelitian ini berupa jurnal-jurnal penelitian terdahulu.

Sumber data yang digunakan untuk mengumpulkan data dalam penelitian ini antaralain terdiri dari data primer dan data sekunder. Menurut Sugiyono (2012) "Data primer adalah sumber data yang langsung memberikan data kepada pengumpul data". Data primer dalam penelitian ini didapatkan dengan cara menyebarkan kuesioner. Kuesioner dibuat untuk menganalisis data mengenai pengaruh periklanan dan citra merek terhadap keputusan pembelian smartphone Samsung yang kemudian disebarkan kepada responden penelitian. Jawaban dari responden kemudian diukur menggunakan Skala Likert yang mempunyai lima tingkatan jawaban sangat setuju diberi skor 5, setuju diberi skor 4, netral diberi skor 3, tidak setuju diberi skor 2, dan sangat tidak setuju diberi skor 1.

Menurut Sugiyono (2012) "Data sekunder adalah sumber data yang tidak memberikan informasi secara langsung kepada pengumpul data. Sumber sekunder ini dapat berupa hasil pengolahan lebih lanjut dari data primer yang disajikan dalam bentuk lain atau dari oranglain". Data sekunder dalam penelitian ini adalah berasal dari referensi buku-buku, internet dan jurnal penelitian yang berhubungan dengan penelitian ini yaitu mengenai periklanan, citra merek, keputusan pembelian.

\section{Populasi dan Sampel Populasi}

Menurut Sugiyono (2017) "populasi adalah wilayah generalisasi yang terdiri atas : objek/subjek yang mempunyai kuantitas dan karakteristik tertentu yang ditetapkan oleh peneliti untuk dipelajari dan kemudian ditarik kesimpulannya". Populasi dalam penelitian ini adalah mahasiswa Fakultas Ekonomi Universitas Krisnadwipayana yang menggunakan smartphone Samsung sejumlah mahasiswa reguler pagi angkatan tahun 2016 adalah sebanyak 137 orang yang terdiri dari 84 orang mahasiswa jurusan manajemen dan 53 orang mahasiswa jurusan akuntansi.

\section{Sampel}

Menurut Sugiyono (2017) "Sampel adalah bagian dari jumlah dan karakteristik yang dimiliki oleh populasi tersebut". Teknik pengambilan sampel dalam penelitian ini menggunakan teknik non probability sampling yaitu merupakan teknik pengambilan sampel yang tidak memberikan peluang yang sama bagi setiap unsur atau anggota populasi yang dipilih untuk dijadikan sampel. Pengambilan sampel dalam penelitian ini menggunakan teknik purpossive sampling yaitu teknik pengambilan sampel berdasarkan pertimbangan khusus. Kriteria yang dijadikan responden dalam penelitian ini adalah mahasiswa fakultas ekonomi, 
mahasiswa yang menggunakan handphone android Samsung dan mahasiswa yang pernah melihat tayangan iklan Samsung. Untuk menentukan sampel penelitian dari populasi yang telah diketahui, maka perhitungan pengambilan jumlah sampel dalam penelitian ini menggunakan rumus Slovin. Hasil perhitungan Slovin sebanyak 58. Sehingga sampel penelitian sebanyak 58 responden.

\section{Uji Kualitas Data Uji Validitas}

Uji validitas merupakan suatu alat yang menunjukan seberapa jauh alat ukur yang digunakan dalam penelitian mampu untuk mengetahui tingkat kepastian item pernyataan dalam kuesioner. Suatu instrument dikatakan valid jika instrument tersebut tidak menyimpang dari gambaran tentang variabel yang sedang diteliti. Menurut Sugiyono (2016), menyatakan bahwa "data dikatakan valid jika nilai $\mathrm{r}=$ 0,30. Jadi, jika nilai $r$ kurang dari 0,30 ( $r<$ 0,30 ) maka instrument tersebut dikatakan tidak valid.

\section{Uji Reliabilitas}

Menurut Ghozali (2016) "realibilitas adalah alat untuk mengukur suatu kuesioner yang menunjukan derajat dipercaya". Suatu kuesioner dapat dikatakan reliable jika jawaban yang diberikan responden terhadap pertanyaan atau pernyataan adalah konsisten atau stabil. Sehingga jawaban tersebut dapat menghasilkan data yang cukup dipercaya untuk digunakan sebagai alat pengumpul data. SPSS memberikan fasilitas untuk mengukur reliabilitas dengan uji statstik

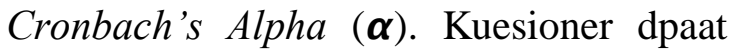
dikatakan reliable jika nilai koefisien Alpha lebih dari 0,60.

\section{HASIL PENELITIAN DAN \\ PEMBAHASAN \\ Uji Kualitas Data \\ Uji Validitas}

Uji validitas adalah suatu ukuran yang menunjukan tingkat keabsahan dan kevalidan suatu instrument pernyataan kuesioner yang digunakan dalam suatu penelitian. Uji valdiitas dilakukan dengan melihat korelasi antar skor masing-masing item pernyataan dengan skor total. Dari hasil olah data menunjukan bahwa semua pernyataan dalam kuesioner adalah valid.

\section{Uji Reliabilitas}

Setelah melakukan uji validitas, maka langkah selanjutnya adalah melakukan uji reliabilitas. Uji reliabilitas adalah alat uji untuk mengetahui sejauh mana konsistensi dan keandalan dari suatu intrumen penelitian. Diperoleh hasil output bahwa hasil dari nilai cronbach alpha lebih besar dari nilai rule of thumb yakni $0,60(>, 0,60)$, sehingga dapat disimpulkan bahwa seluruh pernyataan dari variabel periklanan, citra merek dan keputusan pembelian dinyatakan reliable.

\section{Uji Hipotesis}

\section{Pengaruh Parsial Variabel Periklanan Terhadap Keputusan Pembelian Handphone Merek Samsung.}

Hasil koefisien determinasi $\left(\mathrm{R}^{2}\right)$ sebesar 0,367, artinya konstribusi periklanan kepada keputusan pembelian sebesar $36,7 \%$, sedangkan sisanya sebesar $63,3 \%$ disumbangkan oleh faktor lain yang tidak dijelaskan dalam penelitian ini seperti harga, kualitas produk dan lainlain.

Periklanan berpengaruh positif dan signifikan terhadap keputusan pembelian. Koefisien regresi periklanan bertanda positif sebesar 0,636, artinya jika ada peningkatan kegiatan periklanan sebesar satu kali, maka akan mempercepat keputusan pembelian sebesar 0,636 kali atau sebaliknya. Persamaan regresi sebagai berikut:

$$
\mathrm{Y}=12,982+0,636 \mathrm{X}_{1}
$$

Berdasarkan analisis diatas hipotesis pertama terbukti. 


\section{Pengaruh Parsial Variabel Citra Merek Terhadap Keputusan Pembelian Handphone Merek Samsung.}

Berdasarkan Tabel 3, koefisien determinasi $\left(\mathrm{R}^{2}\right)$ sebesar 0,444, artinya konstribusi citra merek kepada keputusan pembelian sebesar 44,4\%, sedangkan sisanya sebesar $55,6 \%$ disumbangkan oleh faktor lain yang tidak dijelaskan dalam penelitian ini seperti garansi dan lain-lain.

Citra merek berpengaruh positif dan signifikan terhadap keputusan pembelian handphone merek Samsung di Fakultas Ekonomi Universitas Krisnadwipayana. Koefisien regresi citra merek bertanda positif yakni sebesar 0,732 , artinya jika ada peningkatan citra merek pada perusahaan Samsung sebesar satu kali maka akan mempercepat keputusan pembelian sebesar 0,732 kali atau sebaliknya. Persamaan regresi sebagai berikut:

$$
\mathrm{Y}=9,866+0,732 \mathrm{X}_{2}
$$

Berdasarkan analisis diatas hipotesis kedua terbukti.

\section{Pengaruh Simultan Variabel Periklanan dan Citra Merek Terhadap Keputusan Pembelian Handphone Merek Samsung.}

Nilai F hitung sebesar 26,596 dapat diartikan bahwa secara bersama-sama variabel periklanan dan citra merek berpengaruh signifikan terhadap keputusan pembelian.

Koefisien determinasi $\left(\mathrm{R}^{2}\right)$ sebesar 0,492 atau $\mathrm{m}$ sebesar 49,2\%. Hal ini berarti bahwa kontribusi periklanan dan citra merek kepada keputusan pembelian sebesar 49,2\% dan sisanya sebesar 50,9\% disumbangkan oleh faktor lain yang lain yang tidak dijelaskan dalam penelitian seperti distribusi, harga dan faktor internal seperti emosi, sikap, kepribadian dan pengalaman seseorang.
Periklanan dan citra merek berpengaruh positif dan signifikan terhadap keputusan pembelian handphone merek Samsung di Fakultas Ekonomi Universitas Krisnadwipayana. Persamaan regresi sebagai berikut:

$$
\mathrm{Y}=6,269+0,306\left(\mathrm{X}_{1}\right)+0,520\left(\mathrm{X}_{2}\right)
$$

Berdasarkan analisis diatas hipotesis ketiga terbukti.

Dari persamaan regresi berganda dapat dilihat arah hubungan yang dihasilkan dari variabel-variabel bebas terhadap variabel terikatnya, dengan asumsi variabel lain konstan. Dari hasil persamaan regresi berganda, dapat dijelaskan sebagai berikut: 1). Koefisien regresi periklanan $\left(\mathrm{X}_{1}\right)$ sebesar 0,306. Artinya jika ada peningkatan kegiatan periklanan sebesar satu kali, maka akan mempercepat keputusan pembelian sebesar 0,306 kali atau sebaliknya dengan asumsi variabel lain konstan. 2). Koefisien regresi citra merek $\left(\mathrm{X}_{2}\right)$ sebesar 0,520 . Artinya jka ada peningkatan citra merek sebesar satu kali, maka akan mempercepat keputusan pembelian sebesar 0,520 kali atau sebaliknya dengan asumsi variabel lainnya konstan.

\section{PEMBAHASAN}

\section{Periklanan}

Periklanan dalam penelitian ini dibentuk oleh misi (mission), pesan (message) dan media. Dalam membentuk keberhasilan periklanan diperlukan adanya misi periklanan, sehingga perusahaan dapat memberikan informasi secara lengkap mengenai produk yang ingin ditawarkan kepada calon pembeli.

Perusahaan Samsung belum cukup berorientasi kepada misi perikalan saja, pesan periklanan juga perlu diperhatikan. Perusahaan Samsung perlu menciptakan iklan yang unik yang berbeda dengan iklan lainnya. Iklan perusahaan Samsung tersebut kemudian akan disebarkan melalui berbagai media agar dapat menarik perhatian konsumen. 
Pembentukan periklanan dibentuk oleh misi, pesan dan media. Hal utama dalam periklanan adalah misi. Misi utama perusahaan Samsung mengadakan periklanan adalah untuk menginformasikan produk secara lengkap. Informasi lengkap ini harus berisi tentang keunggulan-keunggulan yang dimiliki handphone Samsung.

\section{Citra Merek}

Pembentukan citra merek dalam penelitian ini dibentuk oleh citra pembuat, citra produk dan citra pemakai. Dalam menciptakan citra merek diperlukan adanya citra pembuat. Kredibilitas yang dimilki perusahaan Samsung dalam menciptakan handphone terbaik membuat merek Samsung telah dikenal luas oleh masyarakat. Perusahaan Samsung belum cukup hanya berorientasi kepada citra pembuat, citra produk juga perlu diperhatikan. Perusahaan Samsung menciptakan produk buatanya dengan berbagai keunggulan material membuat handphone Samsung lebih tahan lama.

Memiliki desain unik dan spesifikasi yang baik membuat handphone Samsung terkesan highclass dan ekslusif. Perusahaan Samsung dapat memberikan keunggulan-keunggulan yang tidak dimiliki oleh handphone merek lain. Hal ini yang membuat mahasiswa Fakultas Ekonomi Universitas Krisnadwipayana merasa bangga mengunakan handphone Samsung.

Pembentukan citra merek dibentuk oleh citra pembuat, citra produk dan citra pemakai. Hal utama dalam pembentukan citra merek adalah citra pembuat terutama merek Samsung telah dikenal luas. Dengan citra merek yang baik, perusahan Samsung mampu menciptakan kepercayaan konsumen. Kepercayaan konsumen ini dapat dicitapkan dengan cara menjaga dan meningkatkan kualitas produk Samsung, dengan upaya tersebut merek Samsung akan selalu diingat dikalangan masyarakat.

\section{Keputusan Pembelian}

Keputusan pembelian dibentuk oleh kemantapan pada sebuah produk, memberikan rekomendasikan kepada oranglain, dan melakukan pembelian ulang. Dalam menciptakan keputusan pembelian diperlukan adanya kemantapan pada sebuah produk. Kemantapan pada sebuah produk muncul jika kebutuhan konsumen dapat terpenuhi.

Perusahaan Samsung belum cukup hanya berorientasi kemantapan pada sebuah produk, sehingga perlu adanya rekomendasi yang diberikan dari oranglain untuk dapat mempengaruhi keputusan pembelian. Hal ini dianggap penting karena rekomendasi dari oranglain adalah salah satu bukti nyata dari seseorang yang pernah menggunakan handphone Samsung. Rekomendasi ini bisa berasal dari keluarga, teman ataupun rekan kerja. Rekomendasi dari orang lain muncul ketika konsumen telah merasa puas karena kualitas produk handphone Samsung telah teruji.

Hal yang diharapkan perusahaan ketika konsumen merasa puas menggunakan handphone Samsung adalah dengan melakukan pembelian ulang produk. Salah satu faktor konsumen tertarik membeli ulang produk dikarenakan produk tersebut lebih baik dibandingkan dengan merek lainnya.

Pembentukan keputusan pembelian dibentuk oleh kemantapan pada sebuah produk, memberikan rekomendasikan kepada oranglain dan melakukan pembelian ulang. Hal utama dalam pembentukan keputusan pembelian adalah kemantapan pada sebuah produk terutama handphone Samsung harus sesuai dengan kebutuhan konsumen.

\section{Pengaruh Periklanan Terhadap Keputusan Pembelian Handphone Merek Samsung.}

Periklanan mendorong mempercepat keputusan pembelian dikarenakan misi periklanan Samsung dapat dipahami oleh Mahasiswa Fakultas Ekonomi Universitas 
Krisnadwipayana melalui informasi iklan yang lengkap, sehingga mereka merasa mantap menggunakan handphone merek Samsung dan memutuskan untuk melakukan pembelian. Hal ini menunjukan bahwa periklanan berpengaruh terhadap keputusan pembelian. Temuan hasil penelitian ini sejalan dengan penelitian Wahyuni (2016) yang menyatakan bahwa promosi penjualan dan periklanan mempengaruhi keputusan pembelian.

\section{Pengaruh Citra Merek Terhadap Keputusan Pembelian Handphone Merek Samsung}

Citra merek mendorong mempercepat keputusan pembelian dikarenakan citra pembuat dari handphone Samsung telah dikenal luas oleh mahasiswa Fakultas Ekonomi Universitas Krisnadwipayana sehingga mereka merasa mantap menggunakan handphone merek Samsung dan memutuskan untuk melakukan pembelian. Hal ini menunjukan bahwa citra merek berpengaruh terhadap keputusan pembelian. Temuan hasil penelitian ini sejalan dengan penelitian Amilia dan Asmara (2017) yang menyatakan bahwa citra merek, harga, dan kualitas produk mempengaruhi keputusan pembelian.

\section{Pengaruh Periklanan Dan Citra Merek Terhadap Keputusan Pembelian Handphone Merek Samsung.}

Berdasarkan hasil analisis diketahui bahwa periklanan dan citra merek berpengaruh terhadap keputusan pembelian. Penelitian ini sejalan dengan penelitian terdahulu yang dilakukan oleh Prakoso (2015) yang menyatakan bahwa harga, iklan dan citra merek berpengaruh terhadap keputusan pembelian. Semakin tinggi kegiatan periklanan dan popularitas citra merek Samsung, maka akan semakin mempengaruhi keputusan pembelian konsumen.

Temuan hasil penelitian ini menunjukan bahwa periklanan dengan indikator misi yang memberikan dukungan terbesar dapat mempengaruhi keputusan pembelian handphone Samsung. Citra merek dengan indikator citra pembuat dapat mempengaruhi keputusan pembelian. Dapat diartikan bahwa jika periklanan dan citra merek meningkat, maka keputusan pembelian handphone Samsung di Fakultas Ekonomi Univeritas Krisnadwipayana juga akan meningkat pula.

\section{KESIMPULAN DAN SARAN}

\section{Kesimpulan}

Dari hasil perhitungan analisis dan pembahasan mengenai pengaruh periklanan dan citra merek terhadap keputusan pembelian handphone Samsung, dapat ditarik kesimpulan sebagai berikut:

Misi (mission), pesan (message), dan media memberikan dukungan kepada periklanan. Dukungan terbesar pada periklanan adalah misi periklanan terutama informasi dari iklan Samsung lengkap. Dengan memberikan informasi yang lengkap maka fungsi dari periklanan telah berjalan secara optimal. Fungsi periklanan adalah untuk memberikan informasi mengenai suatu jasa atau barang yang disampaikan dari pihak penjual kepada pihak konsumen.

Citra pembuat, citra produk dan citra pemakai memberikan dukungan kepada citra merek. Dukungan terbesar pada citra merek adalah citra pembuat terutama merek Samsung telah dikenal luas. Citra merek yang positif dapat mempengaruhi keputusan pembelian handphone merek Samsung.

Kemantapan pada sebuah produk, memberikan rekomendasi kepada oranglain dan melakukan pembelian ulang memberikan dukungan kepada keputusan pembelian. Dukungan keputusan pembelian terbesar pada keputusan pembelian adalah handphone Samsung sesuai dengan kebutuhan konsumen. handphone yang diciptakan perusahaan Samsung haruslah sesuai dengan 
kebutuhan konsumen, dengan begitu akan dapat mempengaruhi keputusan pembelian.

Berdasarkan hasil penelitian membuktikan bahwa periklanan dan citra merek mendorong keputusan pembelian handphone merek Samsung di Fakultas Ekonomi Universitas Krisnadwipayana baik secara bersama-sama maupun sebagian. Namun demikian pengaruh citra merek lebih dominan dibandingkan dengan periklanan.

\section{Saran}

Berdasarkan pembahasan dan kesimpulan yang telah dikemukakan sebelumnya, terdapat beberapa saran yang dapat diberikan untuk penelitian selanjutnya antaralain sebagai berikut:

Hasil penelitian ini dapat djadikan pertimbangan khususnya dalam pengembangan ilmu manajemen pemasaran yang membahas tentang citra merek dan promosi perusahaan khususnya yaitu promosi melalui periklanan.

Perlu menjadi pertimbangan bagi semua peneliti, terutama penelitian selanjutnya yang akan membahas mengenai periklanan dan citra merek terhadap keputusan pembelian handphone merek Samsung untuk mempertimbangkan kemungkinan penggunaan variabel bebas lainnya yang dapat mempengaruhi keputusan pembelian handphone Samsung seperti harga, kualitas produk, distribusi dan memperhatikan lebih jauh tentang sampel yang digunakan sehingga diharapkan dapat lebih menyempurnakan penelitian yang akan dilakukan.

Perlu menjadi pertimbangan perusahaan melalui berbagai perbaikan berkelanjutan, terutama yang berkaitan dengan pesan (message) yang memberikan konstribusi terendah kepada periklanan, yaitu perusahaan Samsung harus membuat pesan yang disampaikan dalam iklan Samsung lebih jelas dan dibuat lebih menarik. Perusahaan juga dapat mempertimbangkan promosi lainnya seperti melalui event sponsorhip, product placement atau melakukan kegiatan promosi penjualan. Hal ini dilakukan untuk memperkenalkan produk-produk baru keluaran Samsung dan untuk tetap menjaga merek Samsung terus dikenal di kalangan masyarakat.

Perlu menjadi pertimbangan perusahaan Samsung melalui berbagai perbaikan berklanjutan, terutama yang berkaitan dengan citra produk yang memberikan konstribusi terendah kepada citra merek Samsung. Perusahaan Samsung diharapkan dapat memperhatikan tingkatan harga yang ditawarkan perusahaan, kerena harga merupakan salah satu citra produk. Harga yang ditawarkan handphone Samsung diharapkan mampu mencapai semua segmen konsumen mulai dari konsumen kelas menengah keatas sampai menengah kebawah, dengan begitu handphone Samsung akan selalu di pilih semua masyarakat dari berbagai kalangan.

Perlu menjadi pertimbangan perusahaaan Samsung melalui berbagai perbaikan berkelanjutan, terutama yang berkaitan dengan pembelian ulang yang memberikan konstribusi terendah kepada keputusan pembelian handphone merek Samsung.

\section{DAFTAR PUSTAKA}

Aaker, David A \& Biel, Alexander L. 2009. Brand Equity and Advertising: Advertising Role in Building Strong Brands. Hillsdale: Lawrence Erlbaum Associates, Inc

Alma, Buchari. 2013. Manajemen Pemasaran dan Pemasaran Jasa. Bandung : Alfabeta

Amilia, Suri \& Asmara, M. Oloan Nst. 2017.Pengaruh Citra Merek, Harga Dan Kualitas Produk Terhadap Keputusan Pembelian Handphone Merek Xiaomi Di Kota Langsa. Aceh: Jurnal Manajemen dan Keuangan

Ghozali, Imam 2016. Aplikasi Analisis Multivariate dengan program IBM 
SPSS 23. Semarang: BPFE Universitas Diponogoro

Hasan, Ali. 2014. Marketing dan KasusKasus Pilihan. Yogyakarta: CAPS

Keller, Kevin Lane. 2013. Strategic Brand Management: Building, Measuring, and Managing Brand Equity. $4^{\text {th }}$ Edition Harlow. English: Pearson Education Inc

Kotler, Phillip \& Armstrong, Gary. 2014. Principle Of Marketing. $15^{\text {th }}$ edition. New Jersey: Pretince Hall

—. 2016. Prinsip-Prinsip Pemasaran. Edisi 13. Jilid 1. Jakarta :Erlangga

Kotler, Phillip \& Kevin, Lane Keller. 2012. Manajemen Pemasaran. Edisi 12. Jakarta: Erlangga

Kotler, Phillip. 2007. Manajemen Pemasaran. Jilid 1. Edisi 12. Jakarta : PT. Indeks

$$
\text { 2009. Manajemen }
$$

Pemasaran. Edisi 13. Jakarta: Erlangga

Lupiyoadi, Rambat. 2014. Manajemen Pemasaran Jasa. Edisi 3. Jakarta : Salemba Empat
Peter \& Olson. 2013. Perilaku Konsumen dan Strategi Pemasaran. Edisi 9. Jakarta: Salemba Empat

Prakoso, Lukman Arif. 2015. Pengaruh Harga, Iklan Dan Citra Merek Terhadap Keputusan Pembelian Smartphone Android Samsung Galaxy Series. Surakarta: Jurnal Ekonomi

Sugiyono. 2012. Metode Penelitian kuantitatif, kualitatif dan R\&D. Bandung : Alfabeta . 2016. Metode Penelitian Kuantitatif, Kualitatif Dan $R \& D$. Bandung: Alfabeta . 2017. Metode Penelitian Kuantitatif, Kualitatif Dan $R \& D$. Bandung : Alfabeta

Tjiptono, Fandy. 2005. Pemasaran Jasa.Edisi 1. Yogyakarta : Bayumedia Publishing

$\begin{array}{lcr}\text { Management } & 2015 . & \text { Brand } \\ \text { Yogyakarta: Andi } & \& & \text { Strategy. }\end{array}$

Wahyuni, Sri. 2016. Pengaruh Promosi Penjualan Dan Periklanan Terhadap Keputusan Pembelian Pada Tabunan Simpedes PT. Bank Rakyat Indonesia. Jakarta: Jurnal Ekonomi 